\title{
Identifikasi Citra Daun Teh Menggunakan Metode Histogram untuk Deteksi Dini Serangan Awal Hama Empoasca
}

\section{Leaf Image Identification Using Histogram Methods for Early Detection of Empoasca Pests Initial Attack}

\author{
Christophorus Candra Kusumadewa ${ }^{1}$, Supatman ${ }^{2}$ \\ ${ }^{1,2}$ Program Studi Teknik Informatika, Fakultas Teknologi Informasi, Universitas Mercu Buana Yogyakarta \\ Jl. Wates Km. 10 Yogyakarta 55753, Indonesia \\ E-mail: candrakusumadewa@gmail.com¹, supatman@mercubuana-yogya.ac.id²
}

\begin{abstract}
ABSTRAK
Hama Empoasca merupakan salah satu hama utama tanaman teh di Asia. Hama ini sulit dimonitor karena ukurannya kecil, lincah, mampu terbang dan meloncat. Pengamatan serangan hama ini agar lebih praktis dan mudah yaitu dengan cara mengamati gejala serangan awal pada pucuk daun teh. Gejala serangan tersebut dapat diakuisisi dan direpresentasikan dalam bentuk citra digital. Penelitian ini bertujuan menghasilkan sebuah algoritma yang dapat membantu membedakan daun teh muda atau pucuk daun teh yang sehat dan yang terkena gejala awal hama Empoasca.

Sampel pucuk daun teh yang sehat atau terserang hama Empoasca diproses menggunakan image preprocessing dan ektraksi ciri dengan metode histogram serta identifikasi berbasis Neural Network. Ciri yang digunakan pada penelitian ini adalah mean, standard deviasi, dan entropy sebagai masukan neural network. Data pelatihan yang digunakan sebanyak 110 citra, terdiri dari 43 citra data normal dan 23 citra terkena gejala awal hama Empoasca serta data pengujian sebanyak 44 citra. Pengujian algoritma ini menghasilkan unjukkerja terbaik sebesar $95,45 \%$ pada alfa 0,1 dan decalfa 0,5 .
\end{abstract}

Kata Kunci : Daun Teh, Histogram, Neural Network, Learning Vector Quantization.

\begin{abstract}
Empoasca pest is one of the main pest of tea plant in Asia. This pest is difficult to monitor because of its small size, lively, capable of flying and jumping. Observation of this pest attack to make it more practical and easy that is by observing symptoms of early attacks on tea leaf shoots. Symptoms of the attack can be acquired and represented in the form of digital images. This study aims to produce an algorithm that can help distinguish young tea leaves or tea leaf buds are healthy and affected by early symptoms of pests Empoasca.

Samples of healthy tea leaves or pest of Empoasca are processed using image preprocessing and feature extraction with histogram method and Neural Network based identification. The characteristics used in this study are mean, standard deviation, and entropy as input of neural network. The training data used were 110 images, consisting of 43 images of normal data and 23 images affected by the initial symptoms of Empoasca pests and test data of 44 images. Testing of this algorithm yield best performance equal to $95,45 \%$ at alpha 0,1 and decalfa 0,5.
\end{abstract}

Keywords: Tea Leaf, Histogram, Neural Network, Learning Vector Quantization.

\section{Pendahuluan}

Dijaman era globalisasi saat ini perkembangan teknologi sangatlah pesat dan semakin canggih. Teknologi yang canggih memberikan kemudahan bagi pekerjaan manusia, sehingga yang dahulu masih dikerjakan dengan tenaga manusia, kini sudah bisa digantikan oleh tenaga mesin (komputer). Saat ini aplikasi komputer sudah banyak digunakan dalam memperingan pekerjaan manusia, seperti halnya pada bidang kedokteran, kemiliteran, industri, perdagangan, pertanian dan lain sebagainya, sehingga komputer menjadi sebuah alat yang handal dalam membantu kebutuhan manusia saat ini.

Teknologi komputer pun telah digunakan dalam bidang pertanian. Dalam penelitian ini menggunakan media komputer untuk 
mengidentifikasi gejala awal serangan hama Empoasca pada tanaman teh. Hama Empoasca merupakan salah satu hama utama tanaman teh di Asia (Long-Qing, et all., 2015).

Hama ini sulit dimonitor karena ukurannya kecil, lincah, mampu terbang dan meloncat (Long-Qing, et all., 2015). Oleh karena itu pengamatan serangan hama ini agar lebih praktis dan mudah dengan cara mengamati gejala serangan awal pada pucuk daun teh.

\section{Landasan Teori}

\subsection{Empoasca sp}

Serangga Empoasca sp. (Homoptera: Cicadelidae) pada teh dikenal dengan nama umum wereng pucuk teh, green tea-leafhopper, dan ada yang menyebutnya wereng hijau. Pada tanaman teh serangga ini pada tahun 1998 dilaporkan menjadi hama dan menimbulkan kerusakan berat di perkebunan teh Gunung Mas, Jawa Barat (Dharmadi, 1999), dimana sebelumnya serangga ini belum pernah diketahui sebagai hama tanaman teh. Hama tersebut dilaporkan menyerang tanaman teh di kebun Pagilaran, Jawa Tengah pada tahun 2000 (Pachrudin, 2007) dalam Wagiman (2011).

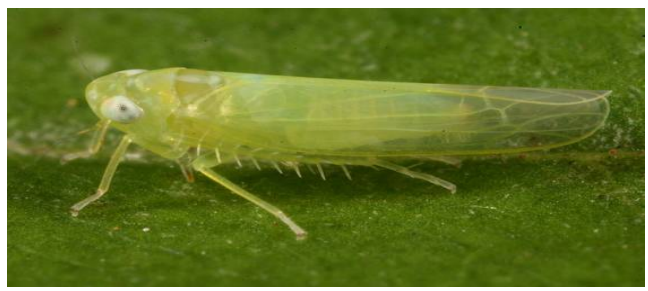

Gambar 1. Hama Empoasca sp

Bioekologi Empoasca sp pada teh sebagai berikut. Metamorfose serangga ini bertipe sederhana, dalam perkembangannya mengalami stadia telur (8-14 hari), nimfe (1114 hari) meliputi lima instar (1, 2, 3, 4, dan 5), dan imago (jantan 10 hari, betina 25 hari), lihat Gambar 2. Tubuh jantan lebih kecil daripada betina. Telur putih agak krem, silinder, dan agak melengkung seperti buah pisang, rata-rata panjangnya sekitar $0,75 \mathrm{~mm}$ (Linda, 2003). Telur satu persatu disisipkan oleh induknya di dalam jaringan pucuk teh, jaringan tulang daun di permukaan bawah daun muda, jaringan ketiak atau tangkai daun muda (Sudarmo, 1992). Produksi telur berkisar antara $200-300$ butir/ekor betina (Kalshoven, 1981).

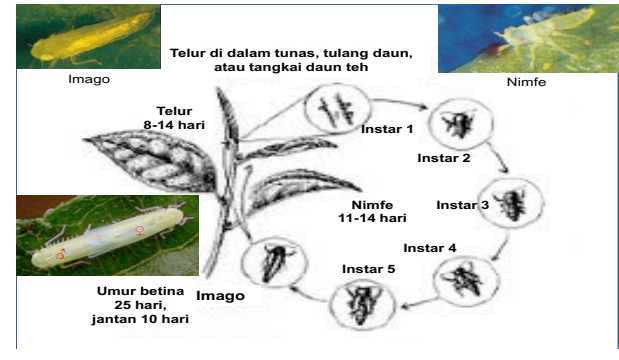

Gambar 2. Siklus hidup dan perkembangan Empoasca flavescens (Ananda Mukhopadhyay dan Mayukh Sarker)

Nimfe dan imago Empoasca sp. Berada pada permukaan bawah daun terutama daun pucuk teh, namun dalam kondisi terpaksa sering juga berada di permukaan atas daun walaupun hanya sesaat (Gambar 3). Stadia nimfe dan imago Empoasca sp. Menghisap daun teh dan pada populasi tinggi dapat menimbulkan kerusakan serius.
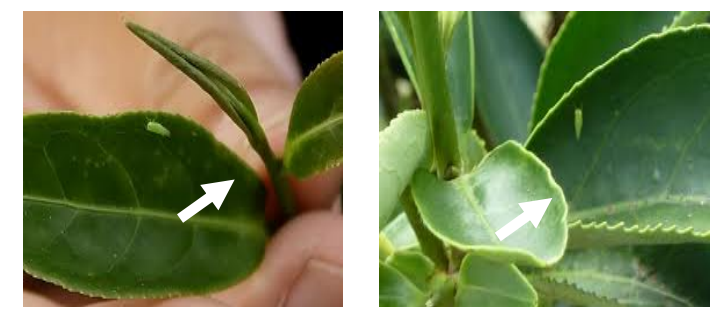

Gambar 3. Empoasca sp. pada daun teh (Wagiman, 2011)

Kepadatan populasi Empoasca sp. Tiga ekor per pucuk sudah dapat menimbulkan kerusakan pucuk teh dari semula berwarna pucat, berubah menjadi kekuningan, dan akhirnya kering (Winasa, 1999). Serangan berat dapat menimbulkan penurunan produksi pucuk teh sebesar 50\% (Dharmadi, 1999).

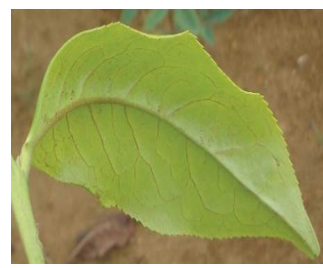

(a)

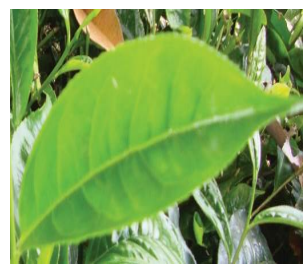

(b)
Gambar 4. (a). Pucuk daun teh yang sehat dan (b). Pucuk daun teh terkena hama Empoasca (Wagiman, 2011)

\subsection{Citra Digital}

Secara umum, pengolahan citra digital menunjuk pada pemrosesan Gambar 2 dimensi 
menggunakan komputer (Putra, 2010). Dalam konteks yang lebih luas, pengolahan citra digital mengacu pada pemrosesan setiap data 2 dimensi. Citra digital merupakan sebuah larik (array) yang berisi nilai-nilai real maupun kompleks yang direpresentasikan dengan deretan bit tertentu.

Citra di dalam komputer disusun oleh sejumlah titik yang disebut piksel. Setiap piksel mempunyai koordinat, yang dinyatakan dalam bentuk $f(\mathrm{x}, \mathrm{y})$ dimana $y$ menyatakan baris dan $x$ menyatakan kolom, seperti Gambar 5.

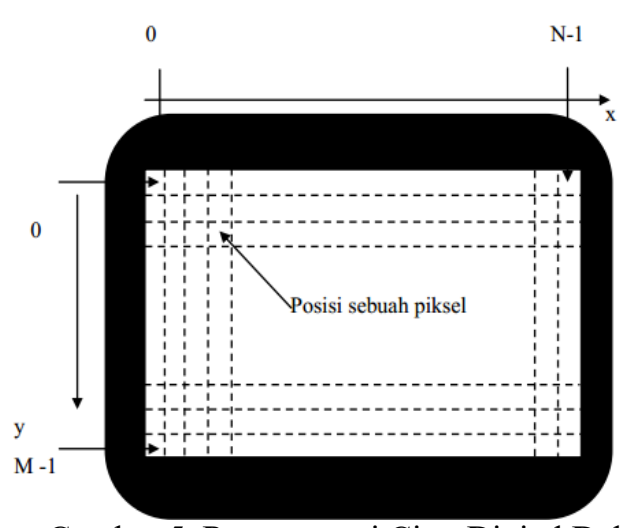

Gambar 5. Representasi Citra Digital Dalam 2 Dimensi (Kadir, 2013)

Piksel pojok kiri-atas mempunyai koordinat $(0,0)$ dan piksel pada pojok kananbawa mempunyai koordinat $(N-1, M-1)$ (Kadir \& Susanto, 2013).

Jika suatu citra berukuran $M$ baris dan $N$ kolom atau biasa dinyatakan sebagai $M \times N$, dimana perpotongan antara baris dan kolom disebut piksel (piksel = picture element) yang memiliki dua parameter yaitu koordinat dan intensitas (warna) pada koordinat $(x, y)$ dengan nilai $f(x, y)$ sehingga dapat ditulis sesuai Persamaan 1.

$f(x, y)=\left(\begin{array}{cccc}f(0,0) & f(0,1) & \cdots & f(0, M-1) \\ f(1,0) & \cdots & \cdots & f(1, M-1) \\ \cdots & \cdots & \cdots & \cdots \\ f(N-1,0) & f(N-1,1) & \cdots & f(N-1, M-1)\end{array}\right)$

Berdasarkan persamaan 1, suatu citra $f(x, y)$ dalam fungsi matematis dapat dituliskan Persamaan 2.

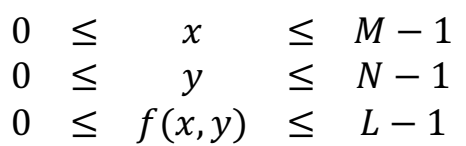

Dalam hal ini :

$M=$ jumlah piksel baris (row) pada array citra, $N=$ jumlah piksel kolom (column) pada array, citra, $L=$ jumlahtingkat keabuan (graylevel)
Besarnya nilai $M, N$ bebas ditentukan, tetapi biasanya merupakan perpangkatan dari 2 yang ditunjukkan pada Persamaan 3.

$M=2^{n}, N=2^{n}$, dan $L=2^{n}$

\subsection{Akuisisi Data}

Akuisisi data adalah tahap dalam mendapatkan citra. Tujuan dari tahap ini adalah untuk menentukan data yang dibutuhkan dan memilih metode perekaman citra digital. Langkah-langkah yang dilakukan dalam tahap ini secara umum dimulai dari persiapan obyek yang akan diambil citranya, alat-alat, sampai pada pencitraan.

\subsection{Cropping}

Cropping adalah proses pemotongan citra pada koordinat tertentu pada area citra. Proses ini dilakukan untuk mengambil bagian yang dirasa penting atau bagian yang memiliki informasi yang paling banyak untuk diolah menggunakan jaringan syaraf tiruan. Selain itu proses ini juga dapat mengubah ukuran citra menjadi lebih kecil, sehingga akan mempercepat proses komputasi. Pada penelitian ini dilakukan cropping pada daerah yang mengindikasikan gejala yaitu pada syaraf daun dengan ukuran 50x50 piksel.

\subsection{Pengolahan Warna}

Sebuah gambar berwarna memiliki core warna yaitu Red, Green, dan Blue. Maka dari itu diperlukan sebuah cara untuk pembacaan nilai-nilai dari R, G, dan B pada suatu pixel.

Salah satu cara untuk menghitung nilai tersebut adalah dengan melakukan normalisasi terhadap ketiga komponen warna tersebut (Munir, R., 2004).

Cara untuk melakukan normalisasi tersebut adalah dengan Persamaan 7.

$r=\frac{\mathrm{R}}{\mathrm{R}+\mathrm{G}+\mathrm{B}}$
$g=\frac{\mathrm{R}}{\mathrm{R}+\mathrm{G}+\mathrm{B}}$
$b=\frac{\mathrm{R}}{\mathrm{R}+\mathrm{G}+\mathrm{B}}$

Dengan normalisasi tersebut didapatkan nilai dari masing-masing $r$, g, dan $b$, dengan range nilai 0-255.

\subsection{Grayscale}

Grayscale adalah suatu format citra atau gambar dimana tiap-tiap pixel gambar hanya terdiri dari 1 komposisi (channel) warna. 
Perbedaan mendasar dengan format $R G B$ ialah pada tiap-tiap pixel gambar terdiri dari komposisi warna yaitu: $R$ (merah), $G$ (hijau), $B$ (biru). Gray yang digunakan pada penelitian ini adalah gray YUV, bisa dirumuskan seperti pada Persamaan 7.

$F=0,299 * R+0,587 * G+0,110 * B$

Dalam hal ini $\mathrm{F}=$ grayscale.

Nilai yang lain juga dapat diberikan untuk ketiga parameter tersebut asalkan total nilai keseluruhannya adalah 1 (satu).

\subsection{Histogram Citra}

Menurut Munir (2004), informasi penting mengenai isi citra digital dapat diketahui dengan membuat histogram citra. Histogram citra adalah grafik yang menggambarkan penyebaran nilai-nilai intensitas pixel dari suatu citra atau bagian tertentu di dalam citra. Dari sebuah histogram dapat diketahui frekuensi kemunculan nisbi (relative) dari intensitas pada citra tersebut. Dari histogram tersebut dihasilkan sebuah data yang akan diguanakan dalam sebuah pengolahan citra.

Histogram secara umum merupakan sebaran atau distribusi frekuensi. Histogram suatu citra didefinisikan sebagai sebaran nilai derajat keabuan citra. Suatu histogram h dari citra grayscale dengan derajat keabuan [0, L-1] akan memiliki sebanyak L derajat keabuan. Misalkan terdapat citra grayscale 8 bit memiliki $\mathrm{L}=2^{8}=256$. Histogram citra digital dengan derajat keabuan $[0, \mathrm{~L}-1]$ adalah suatu fungsi diskrit pada Persamaan 8.

$h(i)=n i(4)$

Dalam hal ini ni $=$ jumlah piksel dengan derajat keabuan i dan $\mathrm{h}(\mathrm{i})=$ histogram citra digital pada derajat keabuan $\mathrm{i}$.

\subsection{Neural Network}

Neural Network (Jaringan Syaraf Tiruan) adalah sebuah metode pemodelan data statistik nonlinier. Neural Network dapat digunakan untuk memodelkan hubungan yang kompleks antara input dan output untuk menemukan polapola pada data (Widodo, 2005).

Neural Network juga bisa dibayangkan seperti otak buatan. Hal ini dikarenakan pemodelan Neural Network dapat dilatih dengan database pembelajaran, sehingga dapat membuatnya cerdas. Untuk lebih jelasnya struktur jaringan syaraf tiruan dapat dilihat pada Gambar 6.

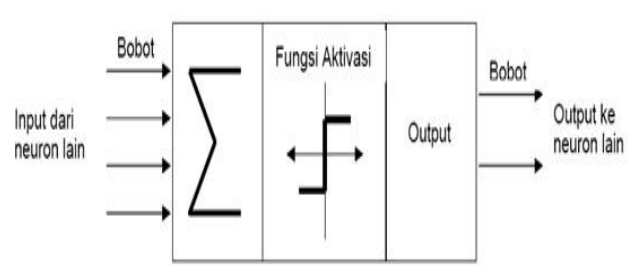

Gambar 6. Struktur jaringan syaraf tiruan (Kusumadewi, 2003)

\subsection{Ekstraksi Ciri Statistik}

Ciri statistik dari histogram yaitu rerata intensitas, varian, standar deviasi dan entropi. Komponen fitur ini dihitung berdasar Persamaan 9.

$$
\begin{aligned}
& m=\sum_{i=0}^{L-1} i \cdot p(i) \\
& \sigma=\sqrt{\sum_{i=1}^{L-1}(i-m)^{2} p(i)} \\
& \text { entropi }=-\sum_{i=0}^{L-1} p(i) \log _{2}(p(i))
\end{aligned}
$$

Dalam hal ini, $i$ adalah aras keabuan pada citra $f$ dan $p(i)$ menyatakan probabilitas kemunculan $i$ dan L menyatakan nilai aras keabuan tertinggi, $\sigma^{2}$ varian, $\sigma$ standar deviasi.

\subsection{Learning Vector Quantization}

Learning Vector Quantization (LVQ) adalah suatu metode untuk melakukan pembelajaran pada lapisan kompetitif yang terawasi. Suatu lapisan kompetitif akan secara otomatis belajar untuk mengklasifikasikan vektor-vektor input. Kelas-kelas yang didapatkan sebagai hasil dari lapisan kompetitif ini hanya tergantung pada jarak antara vektorvektor input. Jika 2 vektor input mendekati sama, maka lapisan kompetitif akan meletakkan kedua vektor input tersebut kedalam kelas yang sama (Kusumadewi,2003).

Menurut Nurkhozin, dkk (2011) LVQ adalah jaringan single layer yang terdiri dari dua lapisan yaitu lapisan input dan output seperti pada Gambar 7.

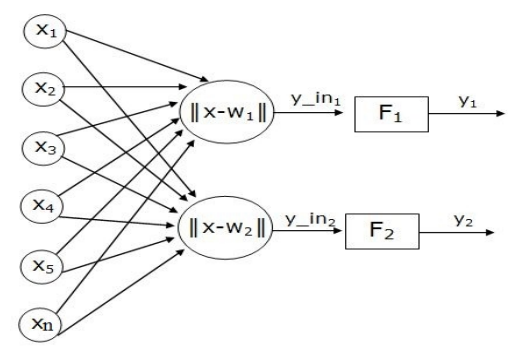

Gambar 1. Arsitektur LVQ 
Keterangan :

$$
\begin{aligned}
& \mathrm{X}=\text { Vektor masukan } \\
& \text { (X1,X2...Xn) } \\
& \mathrm{W}=\text { Vektor bobot } \\
& |\mathrm{X}-\mathrm{W}|=\text { selisih nilai jarak Eucledian } \\
& \text { antara vektor input dengan vektor } \\
& \text { bobot } \\
& \mathrm{F} \quad=\text { Lapisan Kompetitif } \\
& \mathrm{y}_{\text {in }}=\text { Masukan lapisan kompetitif } \\
& \mathrm{y} \quad=\text { output }
\end{aligned}
$$

Langkah 0. inisialisasi vektor referensi inisialisasi laju pelatihan $\alpha(0)$.

Langkah 1. selama syarat berhenti: salah, kerjakan Langkah 2-6.

Langkah 2. Untuk setiap vektor masukan pelatihan x, kerjakan Langkah 34.

Langkah 3. Carilah j sehingga minimum $\| x-$ wj

Langkah 4. Perbaharui wj sebagai berikut :

Bila $\mathrm{T}=\mathrm{Cj}$ maka wj (baru) $=$ wj $($ lama $)+\alpha[\mathrm{x}-$ wj (lama)]

Bila $\mathrm{T} \neq \mathrm{Cj}$ maka wj (baru) $=$ wj (lama) $-\alpha[\mathrm{x}-$ wj (lama)]

Langkah 5. Kurangi laju pelatihan

Langkah 6. Uji syarat berhenti (dapat spesifikasi dengan cacah iterasi atau laju pelatihan apakah sudah mencapai nilai yang cukup kecil) (Widodo, 2005).

\section{METODOLOGI}

\subsection{Materi}

Citra daun teh yang digunakan diambil dari perkebunan teh Nglinggo, Samigaluh Yogyakarta dan perkebunan teh Kemuning, Karanganyar, Jawa Tengah. Data penelitian ini berjumlah 110 data citra daun teh dengan rincian 66 citra digunakan sebagai data latih yang terdiri 43 citra daun normal dan 23 citra yang terkena gejala awal hama empoasca dan 44 citra untuk data uji.

\subsection{Peralatan}

\subsubsection{Perangkat Keras}

Notebook intel i3, harddisk 320GB memori, harddisk, memori 4Gbyte RAM dan sistem operasi Microsoft Windows 7 Profesional untuk membuat program dan pembuatan laporan penelitian.

\subsubsection{Perangkat Lunak}

Perangkat lunak yang digunakan dalam penelitian ini ada tiga macam, yaitu :

a) Software Matlab versi 7.10.0 (R2010a) b) Photoshop versi CS5

c) Microsoft office picture manager

\subsection{Jalannya Penelitian}

Jalannya penelitian identifikasi gejala awal hama Empoasca ditunjukan pada Gambar 8.

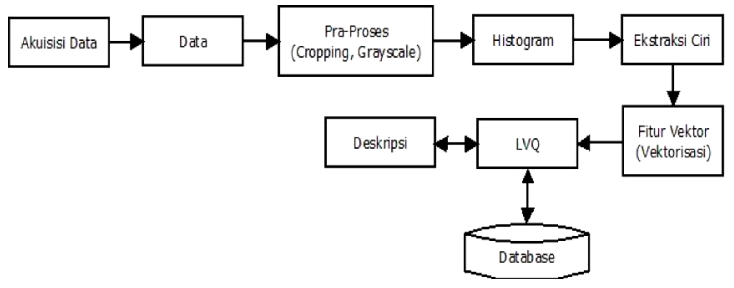

Gambar 8. Blok diagram desain sistem identifikasi daun teh.

\subsubsection{Akuisisi Data}

Akuisisi data merupakan tahapan awal yang dilakukan dalam pengidentifikasian citra daun teh. Alat yang digunakan berupa kamera smartphone dengan kapasitas 23 megapixel dan lensa makro tambahan. Pengambilan citra dilakukan langsung oleh peneliti terhadap daun teh.

\subsubsection{Data}

Dari proses akuisisi data yang dilakukan maka akan dihasilkan data berupa citra bahan. Citra ini selanjutnya akan dilakukan pemrosesan pada tahap berikutnya.

\subsubsection{Cropping}

Pada proses cropping dilakukan secara manual untuk memotong dengan ukuran 50x50 piksel saja pada daerah yang berindikasi yaitu syaraf daun.

\subsubsection{Grayscale}

Setelah citra di potong, proses selanjutnya adalah dengan mengubah citra dari 3 layer menjadi satu layer gray.

\subsubsection{Ekstraksi Ciri}

Ekstraksi ciri merupakan langkah awal dalam melakukan klasifikasi dan interpretasi citra. Proses ini berkaitan dengan kuantisasi karakteristik citra ke dalam sekelompok nilai ciri yang sesuai. Sehingga mendapatkan informasi kuantitatif dari 5 ciri yang dapat membedakan kelas-kelas suatu obyek. Dalam penelitian ini menggunakan 3 ciri yaitu mean (rerata), standar deviasi (std) dan entropi yang diambil dari hasil proses grayscale. 


\subsubsection{Vektorisasi}

Vektorisasi adalah tahapan dimana ciri dari hasil ekstraksi ciri diperoleh dalam bentuk vektor. Ciri tersebut kemudian disimpan dalam database yang digunakan sebagai acuan untuk proses pelatihan. Ciri yang dijadikan adalah hasil dari mean (rerata), standard deviasi (std), dan entropi. Pengenalan data uji dilakukan dengan membandingkan bobot akhir dengan ciri data uji, kemudian mencari jarak terdekat untuk menentukan kelasnya.

\subsubsection{Learning Vector Quantization}

Learning Vector Quantization adalah sebuah metode klasifikasi dimana setiap unit output mempresentasikan sebuah kelas. Setelah proses ekstraksi citra, ciri yang didapatkan dan menjadi database kemudian dimasukkan untuk proses pengenalan menggunakan Learning Vector Quantization. Arsitektur LVQ dapat dilihat pada Gambar 9.

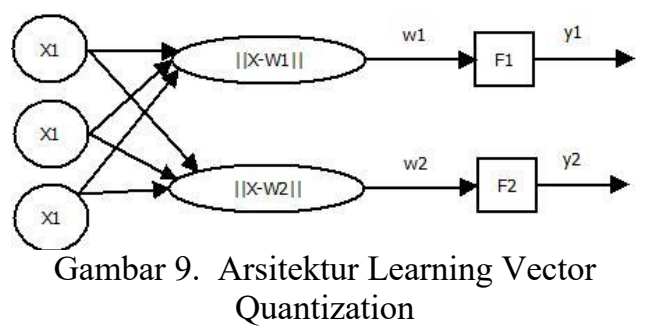

Keterangan :

$\mathrm{X}=$ Vektor masukan $(\mathrm{X} 1, \mathrm{X} 2 \ldots \mathrm{Xn})$,

$\mathrm{W}=$ Vektor bobot,

$|\mathrm{X}-\mathrm{W}|=$ selisih nilai jarak Eucledian antara vektor input dengan vektor bobot,

$\mathrm{F} \quad=$ Lapisan Kompetitif,

y_in = Masukan lapisan kompetitif,

$\mathrm{y} \quad=$ output

Berdasarkan arsitektur Learning Vector Quantization tersebut dapat dikatakan bahwa pelatihan data dimulai dengan mencari jarak terdekat antara data latih dengan bobot awal untuk mendapatkan bobot akhir yang akan digunakan untuk melakukan pengujian.

\section{PEMBAHASAN}

\subsection{Akuisisi Data Citra}

Citra diambil menggunakan kamera handphone yang memiliki kualitas 23 MP. Hasil akuisisi berupa citra digital dengan format .jpg dipindahkan dari smartphone ke komputer untuk dijadikan data dalam penelitian. Data citra daun teh dalam penelitian ini ditunjukan pada Gambar 10 (a) dan Gambar 11 (b).

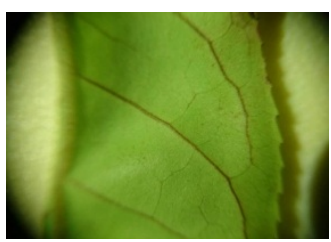

Gambar 10. (a). Citra Daun Teh Bergejala, dan (b). Citra Daun Teh Normal

\subsection{Proses Cropping}

Pada tahap selanjutnya citra di kecilkan dimensinya dengan ukuran piksel 50x50 pada bagian yang mengindikasikan gejala yaitu pada syaraf daun ditunjukkan pada Gambar 11.

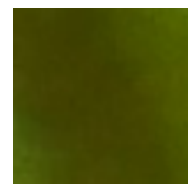

(a)

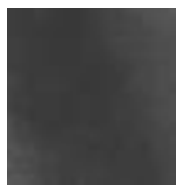

(b)
Gambar 11. (a) Citra Daun Teh Yang Telah Di Crop 50x50, (b) Citra Daun Teh yang telah di Crop dan Grayscale

\subsection{Proses Grayscale}

Setelah didapat hasil dari citra cropping, langkah selanjutnya adalah membuat citra tersebut menjadi aras keabuan seperti Gambar 11(b).

\subsection{Proses Histogram}

Citra daun yang telah di-cropping dan digrayscale di buat histogram dari citra tersebut. Hasil histogram dapat dilihat pada Gambar 12.

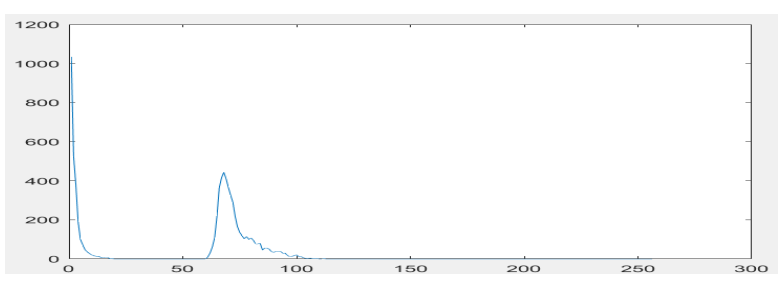

Gambar 12. Hasil Histogram

\subsection{Ekstraksi Ciri}

Berdasarkan histogram citra dauh teh, dilakukan ekstraksi 3 ciri yaitu rerata, standar deviasi, dan entropi. Hasil dari ekstraksi 66 data latih ditunjukkan Tabel 1.

Tabel 1. Hasil Ekstraksi Ciri Data Pelatihan

\begin{tabular}{|c|c|c|c|c|}
\hline No & $\begin{array}{c}\text { Data } \\
\text { Pelatihan }\end{array}$ & $\begin{array}{c}\text { Mean } \\
\text { (rerata) }\end{array}$ & $\begin{array}{c}\text { Standar } \\
\text { Deviasi }\end{array}$ & Entropy \\
\hline 1 & N1 & 114,8132 & 4,4688 & 2,8461 \\
\hline 2 & N2 & 100,3152 & 6,2798 & 2,8668 \\
\hline 3 & N3 & 111,2332 & 8,3980 & 3,3051 \\
\hline
\end{tabular}




\begin{tabular}{|c|c|c|c|c|}
\hline No & $\begin{array}{c}\text { Data } \\
\text { Pelatihan }\end{array}$ & $\begin{array}{c}\text { Mean } \\
\text { (rerata) }\end{array}$ & $\begin{array}{l}\text { Standar } \\
\text { Deviasi }\end{array}$ & Entropy \\
\hline 4 & N4 & 127,8804 & 10,9935 & 3,4036 \\
\hline 5 & N5 & 116,8072 & 5,2947 & 2,9331 \\
\hline 6 & N6 & 107,5172 & 6,4393 & 2,8748 \\
\hline 7 & N7 & 97,3336 & 4,6520 & 2,6741 \\
\hline 8 & N8 & 111,9756 & 6,8772 & 2,9401 \\
\hline 9 & N9 & 108,5624 & 6,3449 & 2,9598 \\
\hline 10 & N10 & 96,6240 & 6,1672 & 2,8255 \\
\hline 11 & N11 & 141,0508 & 4,9377 & 2,9562 \\
\hline 12 & N13 & 113,1480 & 8,0751 & 3,2960 \\
\hline 13 & N14 & 107,5016 & 5,7732 & 2,8863 \\
\hline 14 & N15 & 101,0136 & 4,6490 & 2,7109 \\
\hline 15 & N16 & 102,5224 & 9,0995 & 3,1818 \\
\hline 16 & N17 & 110,5576 & 4,4654 & 2,7767 \\
\hline 17 & N18 & 111,9184 & 8,0926 & 3,0075 \\
\hline 18 & N19 & 93,9192 & 6,6426 & 3,0009 \\
\hline 19 & N20 & 102,8096 & 7,5266 & 3,0783 \\
\hline 20 & N21 & 95,0984 & 4,5927 & 2,7523 \\
\hline 21 & N22 & 96,1176 & 6,2255 & 3,0569 \\
\hline 22 & N24 & 101,4280 & 6,8823 & 2,8399 \\
\hline 23 & N25 & 96,7976 & 3,5097 & 2,5936 \\
\hline 24 & N26 & 105,1016 & 4,4445 & 2,5867 \\
\hline 25 & N27 & 97,8288 & 12,4911 & 3,3074 \\
\hline 26 & N28 & 114,1212 & 10,7573 & 3,4638 \\
\hline 27 & N29 & 100,9892 & 4,4772 & 2,6559 \\
\hline 28 & N30 & 121,5480 & 5,3062 & 2,8905 \\
\hline 29 & N31 & 96,8412 & 5,1401 & 2,8746 \\
\hline 30 & N32 & 122,1972 & 11,0274 & 3,3816 \\
\hline 31 & N33 & 112,6048 & 5,3274 & 2,9341 \\
\hline 31 & N33 & 112,6048 & 5,3274 & 2,9341 \\
\hline 33 & N36 & 91,3828 & 2,9536 & 2,3618 \\
\hline 34 & N37 & 104,2656 & 5,2177 & 2,8782 \\
\hline 35 & $\mathrm{~N} 40$ & 115,4608 & 11,9495 & 3,7038 \\
\hline 36 & N41 & 97,4996 & 5,0237 & 2,7809 \\
\hline 37 & N42 & 93,8852 & 7,2922 & 3,1342 \\
\hline 38 & N43 & 106,6144 & 11,0669 & 3,5414 \\
\hline 39 & N44 & 98,2248 & 8,4182 & 3,2402 \\
\hline 40 & N45 & 94,2700 & 3,7209 & 2,6304 \\
\hline 41 & N47 & 91,5820 & 4,6232 & 2,7125 \\
\hline 42 & N49 & 94,2152 & 5,0457 & 2,6309 \\
\hline 43 & N50 & 114,4280 & 11,0904 & 3,4342 \\
\hline 44 & G1 & 62,2680 & 7,8981 & 3,3688 \\
\hline 45 & G3 & 82,2756 & 9,7761 & 3,5472 \\
\hline 46 & G4 & 84,0844 & 10,3072 & 3,5885 \\
\hline 47 & G5 & 56,2228 & 7,3792 & 2,9973 \\
\hline 48 & G9 & 77,0568 & 14,4645 & 3,8424 \\
\hline 49 & G10 & 85,7608 & 8,6537 & 3,4648 \\
\hline 50 & G17 & 91,0964 & 9,3692 & 3,4137 \\
\hline 51 & G27 & 80,9728 & 16,3993 & 4,0138 \\
\hline 52 & $\mathrm{G} 28$ & 64,7616 & 2,2284 & 2,0589 \\
\hline 53 & G29 & 71,3380 & 3,2604 & 2,3105 \\
\hline 54 & G30 & 66,0036 & 9,5928 & 3,4903 \\
\hline 55 & G31 & 74,0064 & 3,5329 & 2,5840 \\
\hline 56 & G32 & 81,3448 & 5,0782 & 2,7118 \\
\hline 57 & G33 & 72,0020 & 11,8136 & 3,4197 \\
\hline 58 & G34 & 65,1156 & 7,3632 & 3,1246 \\
\hline 59 & G40 & 84,9744 & 12,0268 & 3,6826 \\
\hline 60 & G41 & 66,0036 & 9,5928 & 3,4903 \\
\hline 61 & G42 & 87,2444 & 2,9035 & 2,3815 \\
\hline 62 & G43 & 74,0064 & 3,5329 & 2,5840 \\
\hline 63 & G44 & 84,8004 & 7,0797 & 3,0740 \\
\hline 64 & G45 & 85,9824 & 9,0452 & 3,3475 \\
\hline 65 & G46 & 74,7312 & 3,1629 & 2,4644 \\
\hline 66 & G47 & 70,8080 & 2,1799 & 2,1004 \\
\hline
\end{tabular}

Sedangkan hasil ekstraksi ciri dari 44 citra yang terdapat dalam data uji ditunjukan pada Tabel 2.

Tabel 3. Hasil Ekstraksi Ciri Data Uji \begin{tabular}{|l|l|l|l|l|}
\hline No, & Data Uji & Mean & Std. Dev & Entropy \\
\hline
\end{tabular}

\begin{tabular}{|r|r|r|r|r|} 
& uji1 & 70,0464 & 5,9404 & 3,1400 \\
\hline 2 & uji2 & 73,5212 & 13,2401 & 3,6913 \\
\hline 3 & uji3 & 89,3396 & 3,7221 & 2,5345 \\
\hline 4 & uji4 & 123,9284 & 7,8465 & 3,4072 \\
\hline 5 & uji5 & 104,3732 & 8,6377 & 3,2803 \\
\hline 6 & uji6 & 102,4648 & 23,9626 & 3,8827 \\
\hline 7 & uji7 & 97,2088 & 3,8688 & 2,7355 \\
\hline 8 & uji8 & 114,5636 & 10,6335 & 3,3627 \\
\hline 9 & uji9 & 64,5232 & 3,2091 & 2,3610 \\
\hline 10 & uji10 & 95,5840 & 3,2327 & 2,4968 \\
\hline 11 & uji11 & 91,0964 & 9,3692 & 3,4137 \\
\hline 12 & uji12 & 80,9728 & 16,3993 & 4,0138 \\
\hline 13 & uji13 & 66,0760 & 4,7267 & 2,6550 \\
\hline 14 & uji14 & 62,2680 & 7,8981 & 3,3688 \\
\hline 15 & uji15 & 82,2756 & 9,7761 & 3,5472 \\
\hline 16 & uji16 & 84,0844 & 10,3072 & 3,5885 \\
\hline 17 & uji17 & 56,2228 & 7,3792 & 2,9973 \\
\hline 18 & uji18 & 85,7608 & 8,6537 & 3,4648 \\
\hline 19 & uji19 & 77,0568 & 14,4645 & 3,8424 \\
\hline 20 & uji20 & 64,7616 & 2,2284 & 2,0589 \\
\hline 21 & uji21 & 81,3448 & 5,0782 & 2,7118 \\
\hline 22 & uji22 & 83,9400 & 9,7101 & 3,4558 \\
\hline 23 & uji23 & 87,2444 & 2,9035 & 2,3815 \\
\hline 24 & uji24 & 65,1156 & 7,3632 & 3,1246 \\
\hline 25 & uji25 & 73,0804 & 2,6426 & 2,3464 \\
\hline 26 & uji26 & 84,8004 & 7,0797 & 3,0740 \\
\hline 27 & uji27 & 84,9744 & 12,0268 & 3,6826 \\
\hline 28 & uji28 & 85,9824 & 9,0452 & 3,3475 \\
\hline 29 & uji29 & 74,7312 & 3,1629 & 2,4644 \\
\hline 30 & uji30 & 71,3380 & 3,2604 & 2,3105 \\
\hline 31 & uji31 & 83,9400 & 9,7101 & 3,4558 \\
\hline 32 & uji32 & 73,0804 & 2,6426 & 2,3464 \\
\hline 33 & uji33 & 66,0760 & 4,7267 & 2,6550 \\
\hline 34 & uji34 & 83,1820 & 9,7189 & 3,4897 \\
\hline 35 & uji35 & 83,1820 & 9,7189 & 3,4897 \\
\hline 36 & uji36 & 86,3792 & 6,0822 & 2,8435 \\
\hline 37 & uji37 & 70,8080 & 2,1799 & 2,1004 \\
\hline 38 & uji38 & 97,1044 & 6,1292 & 2,9843 \\
\hline 39 & uji39 & 91,8960 & 7,2912 & 3,1188 \\
\hline 40 & uji40 & 103,0964 & 9,6156 & 3,2304 \\
\hline 41 & uji41 & 116,5960 & 12,6308 & 3,8018 \\
\hline 42 & uji42 & 98,7304 & 7,8095 & 3,2322 \\
\hline & uji43 & 102,5728 & 14,5809 & 3,8598 \\
\hline & uji44 & 94,0736 & 4,9876 & 2,9123 \\
\hline & & & \\
\hline 44 & & & \\
\hline
\end{tabular}

\subsection{Learning Vector Quantization}

Pada proses pelatihan dengan jaringan Learning Vector Quantization digunakan parameter yang dapat mengetahui persentase keberhasilan tertinggi. Pelatihan dilakukan untuk mencari bobot akhir yang digunakan dalam proses pengujian. Parameter LVQ ditunjukan pada Tabel 3.

Tabel 3. Parameter Jaringan LVQ

\begin{tabular}{|l|l|}
\hline \multicolumn{1}{|c|}{ Parameter } & Nilai \\
\hline Jumlah data pelatihan & 66 \\
\hline Jumlah data uji & 44 \\
\hline
\end{tabular}




\begin{tabular}{|l|l|}
\hline Jumlah pola target & $\begin{array}{l}2(1: \text { Normal, 2: } \\
\text { Bergejala })\end{array}$ \\
\hline Variasi laju pelatihan & $\begin{array}{l}0,1 ; 0,01 ; 0,001 ; 0,0 \\
001 ; 0,00001 ; 0,00 \\
0001\end{array}$ \\
\hline Update laju pelatihan & $\begin{array}{l}\alpha \\
=\alpha-\alpha(\operatorname{dec} \alpha)\end{array}$ \\
\hline $\begin{array}{l}\text { Variasi penurunan laju } \\
\text { pelatihan }\end{array}$ & 0,000001 \\
\hline Maksimum iterasi & 1000 \\
\hline
\end{tabular}

Berdasarkan parameter yang terdapat pada Tabel 3, maka dapat dilakukan proses pelatihan. Pada penelitian ini memiliki total data pelatihan 66 data. Untuk data yang digunakan sebagai bobot awal adalah data yang mewakili masing-masing kelas (target) sebagaimana data pada Tabel 4 .

Tabel 4. Bobot Awal

\begin{tabular}{|l|l|c|c|c|}
\hline No & \multicolumn{1}{|c|}{ Data } & Mean & $\begin{array}{c}\text { Standar } \\
\text { Deviasi }\end{array}$ & $\begin{array}{c}\text { Entrop } \\
\mathrm{y}\end{array}$ \\
\hline 1. & Normal & 114,8132 & 4,4688 & 2,8461 \\
\hline 2. & Bergejala & 70,8080 & 2,1799 & 2,1004 \\
\hline
\end{tabular}

Berdasarkan Tabel 4, dapat dilihat bahwa bobot yang nomor 1 untuk kelas 1 dengan kategori NORMAL, sedangkan nomor 2 untuk kelas 2 dengan kategori BERGEJALA.

\subsection{Unjuk Kerja}

Pengujian unjuk kerja dilakukan dengan mengubah parameter laju pelatihan awal (alfa) dan penurunan laju pelatihan ( $d e c$ alfa). Untuk target ada 2 pola, nilai minimum laju pelatihan (min alfa) adalah 0,000001, dan maksimal iterasi nilainya 1000 .

Unjuk kerja dari data pelatihan identifikasi serangan awal hama empoasca pada tanaman teh dengan parameter alfa 0,01 dan decalfa 0,75 dapat dilihat pada Tabel 5 .

Tabel 5. Unjuk Kerja Data Pelatihan

\begin{tabular}{|c|c|c|c|c|}
\hline No. & $\begin{array}{c}\text { Data } \\
\text { Pelatiha } \\
\mathrm{n}\end{array}$ & Target & Hasil & Keterangan \\
\hline 1 & $\mathrm{~N} 1$ & 1 & 1 & Nornal \\
\hline 2 & $\mathrm{~N} 2$ & 1 & 1 & Nornal \\
\hline 3 & $\mathrm{~N} 3$ & 1 & 1 & Nornal \\
\hline 4 & $\mathrm{~N} 4$ & 1 & 1 & Nornal \\
\hline 5 & $\mathrm{~N} 5$ & 1 & 1 & Nornal \\
\hline 6 & $\mathrm{~N} 6$ & 1 & 1 & Nornal \\
\hline 7 & $\mathrm{~N} 7$ & 1 & 1 & Nornal \\
\hline 8 & $\mathrm{~N} 8$ & 1 & 1 & Nornal \\
\hline 9 & $\mathrm{~N} 9$ & 1 & 1 & Nornal \\
\hline 10 & $\mathrm{~N} 10$ & 1 & 1 & Nornal \\
\hline 11 & $\mathrm{~N} 11$ & 1 & 1 & Nornal \\
\hline 12 & $\mathrm{~N} 13$ & 1 & 1 & Nornal \\
\hline
\end{tabular}

\begin{tabular}{|c|c|c|c|c|}
13 & N14 & 1 & 1 & Nornal \\
\hline 14 & G1 & 2 & 2 & Bergejala \\
\hline 15 & G3 & 2 & 2 & Bergejala \\
\hline 16 & G4 & 2 & 2 & Bergejala \\
\hline 17 & G5 & 2 & 2 & Bergejala \\
\hline
\end{tabular}

Tabel 6. Unjukkerja Pengenalan Data Pelatihan (\%) Kumulatif

\begin{tabular}{|c|l|c|c|}
\hline $\begin{array}{c}\text { Penurunan } \\
\text { Laju } \\
\text { Pelatihan } \\
(\text { dec alfa })\end{array}$ & $\begin{array}{c}\text { Laju } \\
\text { Pelatihan } \\
(\text { alfa })\end{array}$ & $\begin{array}{c}\text { Iterasi } \\
\text { Ke }-\end{array}$ & $\begin{array}{c}\text { Unjukkerja } \\
\text { Pengenalan } \\
(\%) \\
\text { Kumulatif }\end{array}$ \\
\hline \multirow{5}{*}{0,1} & 0,1 & 110 & 98,48 \\
\cline { 2 - 4 } & 0,01 & 88 & 98,48 \\
\cline { 2 - 4 } & 0,001 & 66 & 98,48 \\
\cline { 2 - 4 } & 0,0001 & 44 & 96,97 \\
\cline { 2 - 4 } & 0,00001 & 22 & 96,97 \\
\hline \multirow{5}{*}{0,25} & 0,1 & 41 & 98,48 \\
\cline { 2 - 4 } & 0,01 & 33 & 98,48 \\
\cline { 2 - 4 } & 0,001 & 25 & 96,97 \\
\cline { 2 - 4 } & 0,0001 & 17 & 96,97 \\
\cline { 2 - 4 } & 0,00001 & 9 & 96,97 \\
\cline { 2 - 4 } & 0,1 & 17 & 98,48 \\
\cline { 2 - 4 } & 0,01 & 14 & 98,48 \\
\cline { 2 - 4 } & 0,001 & 10 & 96,97 \\
\cline { 2 - 4 } & 0,0001 & 7 & 96,97 \\
\hline \multirow{5}{*}{0,75} & 0,00001 & 4 & 96,97 \\
\cline { 2 - 4 } & 0,1 & 9 & 98,48 \\
\cline { 2 - 4 } & 0,01 & 7 & 98,48 \\
\cline { 2 - 4 } & 0,001 & 5 & 96,97 \\
\cline { 2 - 4 } & 0,0001 & 4 & 96,97 \\
\hline & & 2 & 96,97 \\
\hline
\end{tabular}

Tabel 6 menunjukan hasil prosentase unjukkerja data pelatihan pada tiap alfa dan decalfa, serta menunjukkan hasil unjuk kerja dari citra uji dengan parameter pada Tabel 3. Hasil nilai persentase didapatkan dengan Persamaan 12.

persen $=\frac{\text { citra yang dikenali }}{\text { jumlah citra pelatihan }} \times 100 \%$

Berdasarkan hasil unjuk kerja pada Tabel 6, didapatkan hasil akurasi identifikasi dini gejala awal serangan hama empoasca terbaik menggunakan parameter dengan nilai alfa $(\alpha)=$ 0,01 dan nilai decalfa $($ dec $\alpha)=0,75$ pada iterasi ke-7, karena memiliki nilai iterasi terkecil dengan hasil persentase tertinggi. Kemudian dijadikan nilai bobot akhir yang nantinya akan digunakan untuk proses pengujian. Bobot akhir dapat dilihat pada Tabel 7.

Tabel 7. Tabel Bobot Akhir

\begin{tabular}{|l|l|c|c|c|}
\hline No & \multicolumn{1}{|c|}{ Data } & Mean & $\begin{array}{c}\text { Standar } \\
\text { Deviasi }\end{array}$ & Entropy \\
\hline 1. & Normal & 108.2178 & 6.0067 & 2.9311 \\
\hline 2. & Bergejala & 72.2477 & 4.5623 & 2.5265 \\
\hline
\end{tabular}

Setelah bobot akhir diperoleh, selanjutnya melakukan pengujian menggunakan data uji. Pengujian ini 
dimaksudkan untuk mencari jarak terdekat antara bobot akhir dengan data uji setiap kelasnya. Hasil pengujian perbandingan jarak antar kelas menggunakan data uji dapat dilihat pada Tabel 8.

Tabel 8. Perbandingan Jarak Antar Kelas Pada Data Uji

\begin{tabular}{|c|c|c|c|c|}
\hline \multirow{2}{*}{ No. } & \multirow{2}{*}{$\begin{array}{c}\text { Data } \\
\text { Uji }\end{array}$} & \multicolumn{3}{|c|}{ Jarak } \\
\hline & & Kelas 1 & Kelas 2 & Terdekat \\
\hline 1 & uji1 & 38,1720 & 2,6686 & 2,6686 \\
\hline 2 & uji2 & 35,4507 & 8,8477 & 8,8477 \\
\hline 3 & uji3 & 19,0201 & 17,1125 & 17,1125 \\
\hline 4 & uji4 & 15,8251 & 51,7924 & 15,8251 \\
\hline 5 & uji5 & 4,6717 & 32,3917 & 4,6717 \\
\hline 6 & uji6 & 18,8790 & 35,9344 & 18,8790 \\
\hline 7 & uji7 & 11,2164 & 24,9716 & 11,2164 \\
\hline 8 & uji8 & 7,8653 & 42,7574 & 7,8653 \\
\hline 9 & uji9 & 43,7878 & 7,8439 & 7,8439 \\
\hline 10 & uji10 & 12,9420 & 23,3741 & 12,9420 \\
\hline 11 & uji11 & 17,4551 & 19,4722 & 17,4551 \\
\hline 12 & uji12 & 29,1799 & 14,7801 & 14,7801 \\
\hline 13 & uji13 & 42,1621 & 6,1753 & 6,1753 \\
\hline 14 & uji14 & 45,9908 & 10,5561 & 10,5561 \\
\hline 15 & uji15 & 26,2218 & 11,3483 & 11,3483 \\
\hline 16 & uji16 & 24,5224 & 13,1999 & 13,1999 \\
\hline 17 & uji17 & 52,0131 & 16,2774 & 16,2774 \\
\hline 18 & uji18 & 22,6187 & 14,1500 & 14,1500 \\
\hline 19 & uji19 & 32,3013 & 11,0866 & 11,0866 \\
\hline 20 & uji20 & 43,6289 & 7,8555 & 7,8555 \\
\hline 21 & uji21 & 26,8899 & 9,1136 & 9,1136 \\
\hline 22 & uji22 & 24,5642 & 12,8091 & 12,8091 \\
\hline 23 & uji23 & 21,2088 & 15,0888 & 15,0888 \\
\hline 24 & uji24 & 43,1240 & 7,6857 & 7,6857 \\
\hline 25 & uji 25 & 35,3029 & 2,1002 & 2,1002 \\
\hline 26 & uji26 & 23,4424 & 12,8143 & 12,8143 \\
\hline 27 & uji27 & 24,0221 & 14,7994 & 14,7994 \\
\hline 28 & uji28 & 22,4459 & 14,4710 & 14,4710 \\
\hline 29 & uji29 & 33,6104 & 2,8513 & 2,8513 \\
\hline 30 & uji30 & 36,9871 & 1,6029 & 1,6029 \\
\hline 31 & uji31 & 24,5642 & 12,8091 & 12,8091 \\
\hline 32 & uji32 & 35,3029 & 2,1002 & 2,1002 \\
\hline 33 & uji33 & 42,1621 & 6,1753 & 6,1753 \\
\hline 34 & uji34 & 25,3157 & 12,1275 & 12,1275 \\
\hline 35 & uji35 & 25,3157 & 12,1275 & 12,1275 \\
\hline 36 & uji36 & 21,8389 & 14,2165 & 14,2165 \\
\hline 37 & uji37 & 37,6142 & 2,8161 & 2,8161 \\
\hline 38 & uji38 & 11,1142 & 24,9102 & 11,1142 \\
\hline 39 & uji39 & 16,3733 & 19,8457 & 16,3733 \\
\hline 40 & uji 40 & 6,2723 & 31,2677 & 6,2723 \\
\hline 41 & uji41 & 10,7159 & 45,0943 & 10,7159 \\
\hline 42 & uji 42 & 9,6618 & 26,6903 & 9,6618 \\
\hline 43 & uji43 & 10,3075 & 31,9650 & 10,3075 \\
\hline 44 & uji44 & 14,1809 & 21,8334 & 14,1809 \\
\hline
\end{tabular}

Sebelum dilakukan ekstraksi ciri, data citra yang sudah dilakukan pre-proses awal, kemudian data citra diproses dengan algoritma
LVQ. Proses selanjutnya adalah identifikasi, pada tahap pelatihan sistem akan dilatih untuk mengenali target yang sudah ditentukan, apakah hasilnya sesuai atau tidak sesuai dengan target. Jumlah target yang digunakan banyaknya sesuai atau sama dengan jumlah data pelatihan yang digunakan dalam penelitian ini. Pada awal pelatihan data diberikan nilai bobot, yaitu bobot awal yang menghubungkan setiap neuron pada lapisan input ke neuron pertama pada lapisan output.

Adapun Kinerja kumulatif dari pelatihan LVQ ditunjukkan oleh Gambar 13.

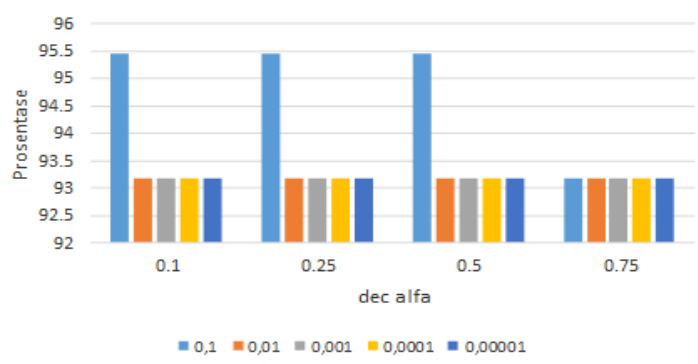

Gambar 13. Kinerja Pelatihan

Adapun iterasi yang dihasilkan pada setiap parameter yang telah dibahas pada materi sebelumnya ditunjukkan pada Gambar 14.

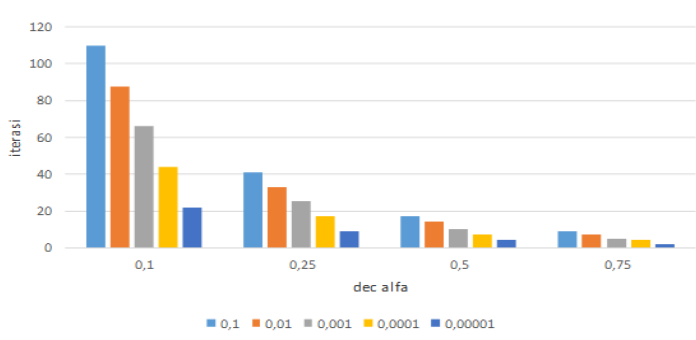

Gambar 14. Jumlah Iterasi Pada Pelatihan

Berdasarkan Gambar 14 didapatkan hasil iterasi terkecil jika menggunakan nilai parameter alfa 0,00001 dan dec alfa 0.75 yaitu 2. Sedangkan iterasi terbesar didapat jika menggunakan nilai parameter afla 0,1 dan dec alfa 0,1. Dalam penelitian ini didapatkan unjukkerja kumulatif tertinggi yaitu 95,45\% pada iterasi terkecil dengan parameter alfa 0,1 dan dec alfa 0,5.

\section{KESIMPULAN}

Identifikasi Citra Daun Teh Menggunakan Metode Histogram Untuk Deteksi Dini Serangan Awal Hama Empoasca dengan 44 data uji memperoleh unjukkerja sebesar $95,45 \%$ pada parameter alfa 0,1 dan dec alfa 0,5 . 


\section{DAFTAR PUSTAKA}

Dhamadi, A. 1999. Empoasca sp. hama baru di perkebunan teh. Prosiding. Seminar Nasional Peranan Entomologi dalam Pengendalian Hama yang Ramah Lingkungan dan Ekonomis. PEI Cabang Bogor. Bogor: 16 Februari 1999. p.: 6050610 .

Kadir, A., Susanto, Adhi. 2013. Teori dan Aplikasi Pengolahan Citra.

Kalshoven. 1981. Teh pests of crops in Indonesia. Translated and revised by PA Van der Laan. PT Ichtiar Baru VanHoeve, Jakarta.

Kusumadewi, S. 2003. Artificial Intelligence (Teknik dan Aplikasinya). Yogyakarta: Graha Ilmu

Linda. 2003. Biologi Empoasca flavescens (F.) (Homoptera: Cicadellidae) pada teh (Camellia sinensis (L.) O Kuntze. Skripsi. Fakultas Pertanian IPB.

Long-QingShi, Zhao-HuaZeng, HuoShuiHuang, Yong-MeiZhou, LietteVasseur, Min-ShengYou. 2015. Identification of Empoascaonukii (Hemiptera: Cicadellidae) and Monitoring of its Populations in the Tea Plantations of South China. Journal of Economic Entomology 108(3):10251033

Munir, R., (2004). Pengolahan citra digital dengan pendekatan algoritmik. Bandung: Informatika.

Putra, D. (2010). Pengolahan Citra Digital. Yogyakarta: Andi.

Sudarmo, S. 1992. Pengendalian serangga hama dan penyakit kapas. Kanisius, Yogyakarta

Wagiman, F. X., B. Triman, R. D. Sinaga, B. Y. Rahmautama, M. Y. Ade. 2011. Evaluasi ketahanan klon-klon teh PGL terpilih terhadap serangan Empoasca sp.LaporanAkhir. Hibah PenelitianUnggulan Fakultas Pertanian UGM Tahun Anggaran 2011

Widodo, T. S. (2005). Sistem Neuro Fuzzy untuk Pengolahan Informasi. Yogyakarta: Graha Ilmu.

Winasa, IW. 1999. Pengaruh insektisida beta sipermetrin dan beta silfutrin terhadap kelimpahan populasi Empoasca sp. pada pertanaman teh di Desa Banyuwangi, Kecamatan Cigudeg, Bogor. Fakultas Pertanian IPB. 